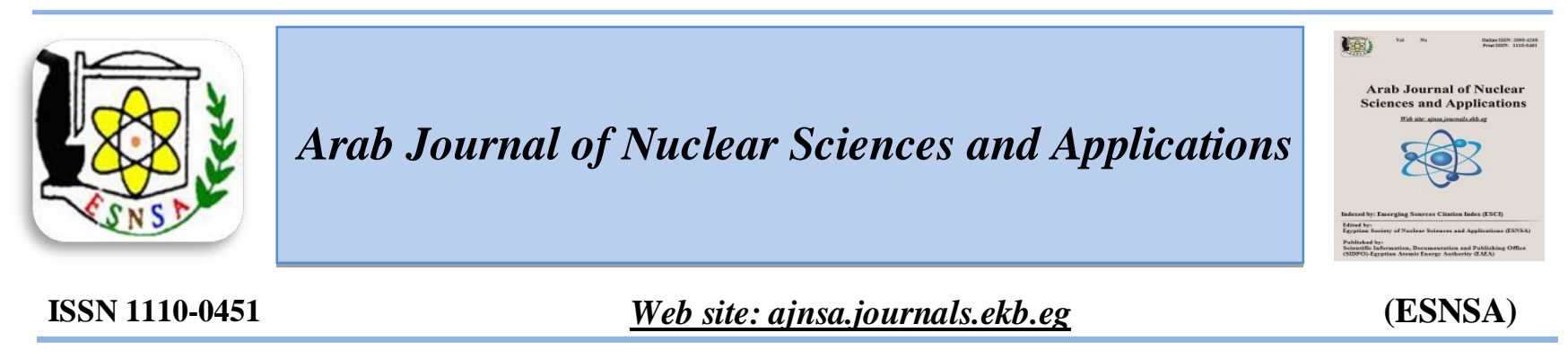

\title{
Chemical Treatment of El Missikat Fluorite-Bearing ore Material, Egypt, for Recovery of Pure Yttrium Oxide
}

\author{
Khalil, M.M.H. ${ }^{(1)}$, El Hussaini, O.M. ${ }^{(2)}$, Abd El Wahab, G.M. ${ }^{(2)}$, Swafy S.K ${ }^{(2)}$ \\ and Khalafalla M.S ${ }^{(2)}$ \\ ${ }^{(1)}$ Faculty of Science, Ain Shams University, Cairo, Egypt \\ ${ }^{(2)}$ Nuclear Materials Authority, Cairo, Egypt
}

\begin{abstract}
Received $1^{\text {st }}$ Mar 2017 Accepted $20^{\text {th }}$ Apr 2017

El Missikat fluorite-bearing ore material, Eastern Desert, Egypt, has been identified as containing a quantity of heavy rare earth elements (REE) such as yttrium fluorite mineral. Rare earth concentrate prepared from sulfate solution of El Missikat fluorite- bearing ore material assays $0.615 \%$ of REE. The solution was prepared from ore material by two subsequent thermal steps namely; fluorine deactivation by $\mathrm{MgO}$ and roasting by $\left(\mathrm{NH}_{4}\right)_{2} \mathrm{SO}_{4}$. The deactivated roasted matrix was leached with hot distilled $\mathrm{H}_{2} \mathrm{O}$ to prepare the solution which assays $0.846 \mathrm{~g} / \mathrm{L}$ of REE. This solution was treated with $20 \mathrm{~g}$ of oxalic acid to produce impure $\mathrm{RE}$ oxalate cake which was ignited at $950^{\circ} \mathrm{C}$. It was then dissolved in concentrated $\mathrm{HNO}_{3}$ to prepare the RE nitrate solution for extracting yttrium using tri butyl phosphate (TBP) in kerosene. The produced yttrium oxide was of $97.2 \%$ purity.
\end{abstract}

Keywords: Yttrium, Extraction, TBP, Fluorite- bearing ore material

\section{Introduction}

Rare earths (lanthanides, yttrium and scandium) are important elements in photo-electronic and metallurgical industries as well as in nuclear energy programs. The demand for rare earth elements and their alloys as structural materials, fluxes, radiation detectors, diluent of plutonium etc. in nuclear technology is steadily increasing. High purity yttrium is often required, for a variety of uses in these specialized areas, [1]. Gabal ElMissikat occurs as a high mountain peak of younger granites (675 m above sea level) intruding the low lying older granitites. Field relationships and observations confirm the presence of some different rock units such as: metavolcanics, older granitites, porphyry dyke swarms and younger granites. These granites are composed of quartz, alkali feldspar, plagioclase, biotite and muscovite with minor amounts of fluorite, zircon, rutile, apatite, monazite, epidote and topaz. Opaques, kaoilinite and sercicite, kaolinite and muscovite are found as secondary minerals [2].

According to Abd El Wraith et al. [3], El Missikat younger granite is rich in fluorine and high heavy REE (Y- group) enrichment in comparison with light $\mathrm{REE}$ (Ce - group). Fluorite $\left(\mathrm{CaF}_{2}\right)$ and yttrium fluorite $(\mathrm{Ca}, \mathrm{Y}) \mathrm{F}_{2}$ which have a widespread occurrence as a common mineral ore deposits. The deep green fluorite contains $\mathrm{Yb}_{2} \mathrm{O}_{3}$ and $\mathrm{Y}_{2} \mathrm{O}_{3}$, [4]. Highly radioactive fluorite- bearing granite in EL Missikat occurs as blue to violet crystals due to the presence of $U$ and Th in crystal lattice of the fluorite [5]. The conventional acidic or alkaline processing of El Missikat fluorite -bearing ore material for extracting REE, $\mathrm{U}$ and $\mathrm{Cd}$ have a serious environmental problems caused by $\mathrm{HF}$ and $\mathrm{SO}_{2}$ evolution. Thus, the nonconventional processing might be preferred for such type of raw materials via two essential steps including thermal fluorine deactivation followed by roasting of the

Corresponding author: Khalil, M.M.H.

DOI: 10.21608/ajnsa.2018.12397

(C) Scientific Information, Documentation and Publishing Office (SIDPO)-EAEA 
deactivated matrix. Fluorine deactivation process was carried out using MgO (to avoid the formation refractory insoluble REE fluorides) as the equation below, [6]:

$2 \mathrm{RE}\left(\mathrm{FCO}_{3}\right)+\mathrm{MgO} \rightarrow \mathrm{RE}_{2} \mathrm{O}_{3}+\mathrm{MgF} \mathrm{F}_{2}+2 \mathrm{CO}_{2}$

A roasting step of the water insoluble fluorine deactivated matrix was carried out using $\left(\mathrm{NH}_{4}\right)_{2} \mathrm{SO}_{4}$ salt to convert it to water soluble matrix.

The separation of REE by solvent extraction (SX) technique depends on the slight difference in the distribution coefficient of an individual REE between two immiscible liquid phases (aqueous and organic phases). Different organic solvents have been used for investigating the separation of individual REE, one of these is tri-butyl phosphate (TBP) [8], di-2-ethylhexyl phosphoric acid (D2EHPA), [1] and carboxylic acids, [9]. Complete separation of yttrium from trivalent cations in aqueous $\mathrm{HNO}_{3}$ can be achieved using tributyl phosphate (TBP), [7]. Finally, this work aims to treatment the refractory fluorite - bearing granite for separation of yttrium using TBP in kerosene from El Missikate Fluorite- bearing ore material.

\section{Experimental}

\section{Materials characterization}

The representative studied raw material was collected from Gabal El Missikat granite, Eastern Desert, Egypt. It was ground to a mesh size of 60, washed with tap water to eliminate slimes. After drying, separation of heavy mineral with bromoform, the heavy fraction was separated isodynamically (1.5 amp nonmagnetic). The separated fractions were picked under the binocular microscope. To identify the mineralogical composition, the prepared sample was examined by X-ray diffraction (PhillipsPW3710) with a generator (PW1830) and $\mathrm{Cu}$ target tube (PW 223/20) operated at $40 \mathrm{kV}$ and $30 \mathrm{~mA}$.

Magnesium oxide used in fluoride deactivation process was locally prepared at Nuclear Materials Authority, Egypt from the bittern solution of the Egyptian salt company El Max, Borg El Arab, Alexandria, [12]. The purity of $\mathrm{MgO}$ is not less than 99\%. Solvent extraction experiments were carried out with AR grade of organic solvent, TBP of purity assays $99.5 \%$. Kerosene (boiling point $160-200^{\circ} \mathrm{C}$ ) was used as diluent. All the other chemicals used in this work are also of high purity.

\section{Procedure}

The chemical composition of the raw material was identified by analyzing the major elements according to [13]. A portion of the fine ground ore material (0.5g) was digested with acid mixture $\left(\mathrm{H}_{2} \mathrm{SO}_{4}, \mathrm{HF}, \quad \mathrm{HNO}_{3}\right.$ and $\left.\mathrm{HCl}\right)$ until complete dissolution and diluted with distilled $\mathrm{H}_{2} \mathrm{O}$ in $250 \mathrm{~mL}$ volumetric flask. Major elements were analyzed and their oxides were determined. For $\mathrm{SiO}_{2}$ analysis, a $0.1 \mathrm{~g}$ weight of the ore material was mixed with $1.0 \mathrm{~g}$ of $\mathrm{NaOH}$ and fused using Lenton muffle furnace. The fused matrix was dissolved in 1:1 $\mathrm{HCl}$ solution and diluted with distilled $\mathrm{H}_{2} \mathrm{O}$ in $250 \mathrm{~mL}$ volumetric flask then silicon content was estimated spectrophotometrically at $\lambda_{640} \mathrm{~nm}$, using Shimadzu UV-vis160A [14].

To estimate the trace elements content in the studied ore material, $1.0 \mathrm{~g}$ was digested in acid mixture (as previously mentioned) until complete dissolution and dilution with distilled $\mathrm{H}_{2} \mathrm{O}$ in 100 $\mathrm{mL}$ volumetric flask. The latter was directed to different analysis techniques for trace elements determination. The elements such as: $\mathrm{Zn}, \mathrm{Ni}, \mathrm{Mn}$, $\mathrm{Cd}, \mathrm{V}, \mathrm{Cu}$...etc. were measured using a Unicam Atomic Absorption Spectrophotometer (model-969 AAS) flame type at principal wavelengths. Uranium was analyzed using an oxidimetric titration method against ammonium metavanadate, [15]. The total REE referring to $\mathrm{Y}$ as heavy rare earth elements was quantitatively analyzed by 0.05 $\%$ Arsenazo (III) at $\lambda_{654} \mathrm{~nm}$ (using Shimadzu UVvis160A spectrophotometer [14].

Determination of the fluoride content was conducted by dissolving $1.0 \mathrm{~g}$ of the ore using $5 \mathrm{ml}$ of $\mathrm{HCl}$ and warming the solution to a lesser degree than the boiling temperature. $2.0 \mathrm{~mL}$ of the solution volume was treated with $0.5 \mathrm{~mL}$ of sodium acetate tri-hydrate to adjust the $\mathrm{pH}$ value to pH 5.0 followed by the addition of the total ionic strength adjustment buffer (TISAB) to adjust the ionic strength of the solution. The latter was then diluted up to $500 \mathrm{~mL}$ with double distilled $\mathrm{H}_{2} \mathrm{O}$ in a plastic flask. A volume of $50 \mathrm{~mL}$ was taken and its fluoride ion concentration was measured by the ion selective electrode (Jenway, UK). 
Preparation of leach liquor

Practically, a $300 \mathrm{~g}$ weight of El Missikat fluoritebearing ground ore material underwent two roasting steps aiming to capture fluorine in closed system. The first step MgO was mixed well with ground ore at ratio (wt/wt) 1:10 and roasted at $350^{\circ} \mathrm{C}$ for $2 \mathrm{~h}$. After cooling the fluoride deactivation matrix was roasted again with $\left(\mathrm{NH}_{4}\right)_{2} \mathrm{SO}_{4}$ salt at(wt/wt) ratio of $1 / 2$ at $200^{\circ} \mathrm{C}$ for $2 \mathrm{~h}$. The produced water soluble fluorine deactivation matrix was leached with distilled hot $\mathrm{H}_{2} \mathrm{O}$ at $\left(80-90^{\circ} \mathrm{C}\right)$ at $\mathrm{S} / \mathrm{L}$ ratio of $1 / 2$ and stirring for $2 \mathrm{~h}$. After cooling, washing and filtration the water insoluble $\mathrm{MgF}_{2}$ residue was collected on filter paper. The filtrate contained the elements: REE, U and $\mathrm{Cd}$ was collected in 2L.This leach liquor's $\mathrm{pH}$ was found to be 8.5; It was used for yttrium extraction.

\section{Separation of total REE}

The prepared leach liquor was adjusted to a $\mathrm{pH}$ of 1.1. It was treated with oxalic acid aiming at precipitate the total REE. About $20 \mathrm{~g} / \mathrm{L}$ of the solution was added with continuous stirring for $1 \mathrm{~h}$. After filtration and washing, the obtained cake was ignited at $850^{\circ} \mathrm{C}$ for $2 \mathrm{~h}$ to produce the $\mathrm{RE}_{2} \mathrm{O}_{3}$ concentrate. The latter was washed, dried and redissolved in $31.5 \% \mathrm{HNO}_{3}$ acid atS/L ratio of $1 / 3$. The REE nitrate solution was directed to solvent extraction for selective recovering of pure yttrium.

\section{Individual separation of yttrium using TBP} Yttrium extraction from the prepared $\mathrm{RE}\left(\mathrm{NO}_{3}\right)_{3}$ solution was performed after $\mathrm{pH}$ adjustment to 1.0 with ammonia solution. It was then mixed with tributyl phosphate, (TBP) (sp.gr.0.979 $\mathrm{g} / \mathrm{mL}$ ) in kerosene to study the relevant extraction parameters such as TBP concentration, $\mathrm{pH}$ value, contact time and volume ratios $(\mathrm{A} / \mathrm{O})$ to optimize yttrium extraction. On the other hand, the concentration of the stripping solution, phase's ratios (O/A) was done for optimizing yttrium stripping.

Concentrated yttrium strip solution was adjusted to a $\mathrm{pH}$ of 1.1 , then $10 \%$ oxalic acid was added with continuous stirring for $1 \mathrm{~h}$. The obtained precipitate was filtered and washed with distilled $\mathrm{H}_{2} \mathrm{O}$ to get rid of any adsorbed impurities. After dryness, the precipitate was ignited at $950^{\circ} \mathrm{C}$ for $3 \mathrm{~h}$ and was identified by means of XRD.

\section{Results and Discussion \\ Mineralogical composition}

The present ore material underwent heavy liquid separation using bromoform where the heavy fraction was Iso-dynamically separated. The binuclear microscope examination of the separated fractions revealed that the non-magnetic fractions containing yttrium fluorite $(\mathrm{Ca}, \mathrm{Y}) \quad \mathrm{F}_{2}$ mineral distributed at 1 and 1.5 Amp. The separated mineral grains were investigated by $\mathrm{XRD}$ as shown in Figure(1): yttrium fluorite $(\mathrm{Ca}, \mathrm{Y}) \mathrm{F}_{2}$, quartz, $\left(\mathrm{SiO}_{2}\right)$, and Musecovite, $(\mathrm{K}, \mathrm{Na})(\mathrm{Al}, \mathrm{Mg}$, $\mathrm{Fe},)_{2}\left(\mathrm{Si}_{3} \mathrm{Al}\right) \mathrm{O}_{10}(\mathrm{OH})_{2}$.

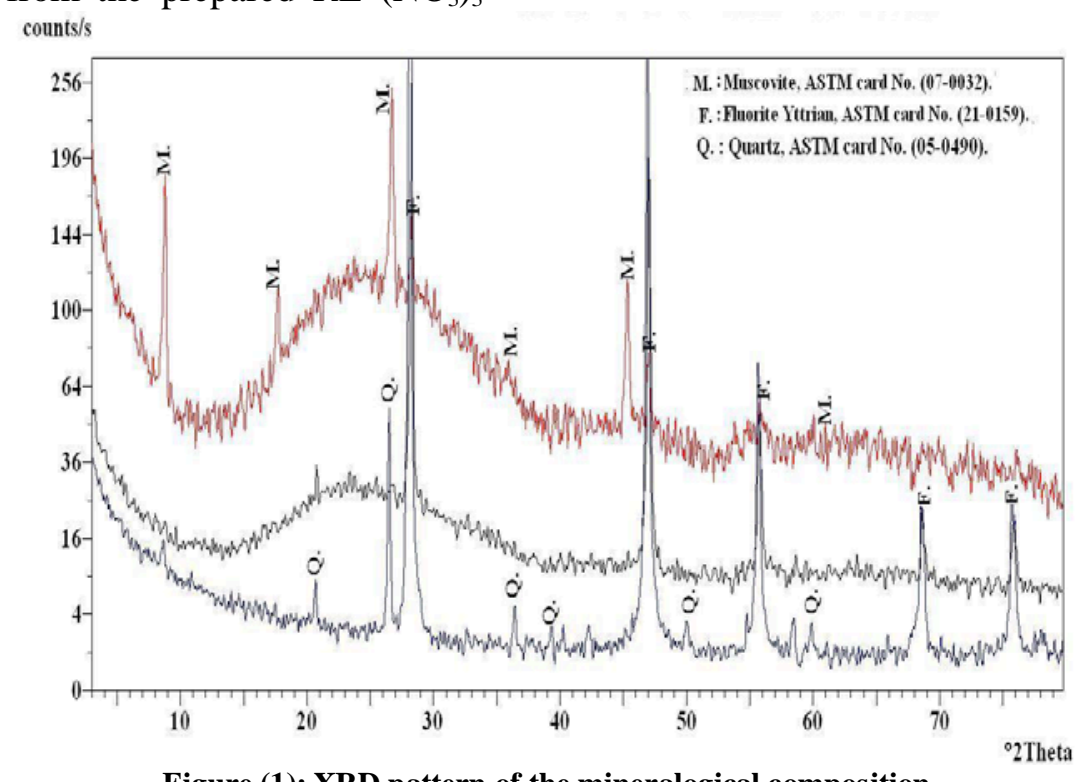

Figure (1): XRD pattern of the mineralogical composition 
Chemical composition

The chemical analysis of ore material is given in Table (1) for major contents and some trace elements. The chemical composition reflects the previously mentioned mineralogical composition.

\section{Leach liquor preparation}

The ground fluorite bearing ore material was mixed with $\mathrm{MgO}$ at (wt/wt) ratio of $10 \%$ and roasted at $350^{\circ} \mathrm{C}$ for $2 \mathrm{~h}$ in a closed system for fluoride deactivation. The fluoride matrix underwent the second roasting step with $\left(\mathrm{NH}_{4}\right)_{2} \mathrm{SO}_{4}$ salt at (wt/wt) ratio of $1 / 2$ and $200^{\circ} \mathrm{C}$ for $2 \mathrm{~h}$. The obtained roasted cake was leached with hot water where the residue was mainly composed of $\mathrm{MgF}_{2}$. On the other hand; the collected filtrates of $2 \mathrm{~L}$ volume had $\mathrm{pH}$ of 8.5 . The content of this leach liquor was given in Table (2).

\section{Separation of total REE}

The total REE $(0.845 \mathrm{~g} / \mathrm{l})$ in the prepared leach solution were selectively precipitated by the gradual addition of oxalic acid $20 \mathrm{~g} / \mathrm{L}$ with continuous stirring. Almost complete precipitation of REE as strong stable insoluble RE oxalate cake was obtained at $\mathrm{pH} 1.1$ and stirring for $60 \mathrm{~min}$. with precipitation efficiency of $98 \%$. These precipitation conditions of $\mathrm{RE}$ oxalate from solutions are quite closed agreement with, [16]; [17], [18] and [19] .The precipitation proceeds according to the following equation: $2 \mathrm{RE}^{3+}+3 \mathrm{H}_{2} \mathrm{C}_{2} \mathrm{O}_{4} \longrightarrow \mathrm{RE}_{2}\left(\mathrm{C}_{2} \mathrm{O}_{4}\right)_{3}$ (solid) $+6 \mathrm{H}^{+}$

After filtration, washing and drying, the obtained RE oxalate cake (3.72g), was ignited at $850^{\circ} \mathrm{C}$ for $2 \mathrm{~h}$. It was washed, dried to produce a weight of 2.1g of $\mathrm{RE}_{2} \mathrm{O}_{3}$ concentrated cake. A weighed portion of the latter was analyzed by UVVIS spectrophotometer to determine the REE concentration and the associated impurities. The purity of $\mathrm{RE}_{2} \mathrm{O}_{3}$ cake achieved $80.3 \%$ with impurities e.g. $18 \%$ of $\mathrm{Ca}, 0.3 \%$ of $\mathrm{Fe}$ and $0.03 \%$ of Mg.

Table (1): Chemical composition of El Missikat ore material

\begin{tabular}{cccc}
\hline Major Contents & Conc., (\%) & Trace elements & Conc. (ppm) \\
\hline $\mathbf{S i O}_{2}$ & 65 & $\mathbf{U}$ & 1600 \\
$\mathbf{T i O}_{2}$ & 0.21 & $\mathbf{N i}$ & 26 \\
$\mathbf{A l}_{2} \mathbf{O}_{3}$ & 3.40 & $\mathbf{C d}$ & 450 \\
$\mathbf{F e}_{2} \mathbf{O}_{3}$ & 1.1 & $\mathbf{C u}$ & 165 \\
$\mathbf{C a O}$ & 5.20 & $\mathbf{V}$ & 30 \\
$\mathbf{M g O}$ & 1.20 & $\mathbf{T h}$ & 40 \\
$\mathbf{N a}_{2} \mathbf{O}$ & 0.2 & ${ }^{*} \mathbf{R E E}$ & 6150 \\
$\mathbf{K}_{\mathbf{2}} \mathbf{O}$ & 0.13 & $\mathbf{C r}$ & 21 \\
$\mathbf{P}_{2} \mathbf{O}_{5}$ & 0.2 & $\mathbf{C u}$ & 65 \\
$\mathbf{F}$ & 20.2 & $\mathbf{C o}$ & 15 \\
${ }^{* *} \mathbf{L . O . I .}$ & 2.06 & $\mathbf{Z n}$ & 17 \\
Total & 98.9 & & \\
\hline
\end{tabular}

* REE: measured as Y (Marchizinco, 2000) ${ }^{(14)}$

${ }^{* *}$ L.O.I .loss of ignition

Table (2): Chemical constituents of the leach liquor

\begin{tabular}{cc}
\hline Elements' Ions & Conc. $(\mathbf{g} / \mathbf{L})$ \\
\hline $\mathrm{REE}^{+3}$ & 0.845 \\
$\mathrm{U}^{+6}$ & 0.225 \\
$\mathrm{Fe}^{+3}$ & 1.13 \\
$\mathrm{Cd}^{+2}$ & 0.064 \\
$\mathrm{~F}^{-}$ & 6 \\
$\mathrm{Si}^{+4}$ & 34 \\
\hline
\end{tabular}




\section{Individual separation of yttrium using TBP}

Due to the great importance of individual REE, the separation of pure $\mathrm{Y}_{2} \mathrm{O}_{3}$ was done via solvent extraction method. So, the $\mathrm{RE}_{2} \mathrm{O}_{3}$ cake was completely dissolved in $31.5 \% \mathrm{HNO}_{3}$ acid at $\mathrm{S} / \mathrm{L}$ ratio of $1 / 3$ and stirring for $2 \mathrm{~h}$ at $70^{\circ} \mathrm{C}$ [19]. The prepared nitrate solution assaying $17 \mathrm{~g} / \mathrm{L}$ of $\mathrm{Y}_{2} \mathrm{O}_{3}$ was used for yttrium extraction by TBP in kerosene in the presence of $0.5 \mathrm{M}$ of EDTA as a complexing agent for masking different impurities. The following parameters were studied to optimize yttrium extraction step.

\section{Effect of TBP concentration}

The effect of varying TBP concentration in the range $0.5-2.0 \mathrm{M}$ in kerosene upon yttrium extraction efficiency (\%) was studied. The $\mathrm{pH}$ of aqueous solution was 0.5 at $\mathrm{A} / \mathrm{O}$ ratio of $1 / 1$ and a contact time of $10 \mathrm{~min}$. After separation, yttrium was analyzed in the aqueous solution. The obtained data shown in Figure(2) revealed that the maximum yttrium extraction efficiency of $64 \%$ was attained at TBP concentration of $1.5 \mathrm{M}$. However, further increase in TBP concentration to 2.0 $\mathrm{M}$ has no influence due to the interfering of other REE metal ions in the aqueous solution.

\section{Effect of $\mathrm{pH}$ value}

The effect of $\mathrm{pH}$ value of the prepared nitrate solution upon yttrium extraction efficiency was studied in the $\mathrm{pH}$ range from 0.5 to 2.0 . The other parameters were kept constant at TBP concentration of $1.5 \mathrm{M}$ in kerosene, $\mathrm{A} / \mathrm{O}$ ratio of $1 / 1$ and contact time of $10 \mathrm{~min}$. The obtained data in Figure (3) indicated that the percentage of yttrium extraction efficiency increased from 64 to $81.2 \%$ with increasing the $\mathrm{pH}$ value of the nitrate solution from 0.5 to 1.0 . Further increase in $\mathrm{pH}$ values to 1.5 and 2.0 have a reverse effect, where yttrium extraction efficiency decreased to $70.3 \%$.

\section{Effect of contact time}

Figure (4) shows the effect of contact time (shaking time) upon yttrium extraction efficiency from the nitrate solution of $\mathrm{pH} 1.0$ at $\mathrm{A} / \mathrm{O}$ ratio of $1 / 1$ and shaking at different time ranging from 5 to $20 \mathrm{~min}$. The data indicates that, the extraction efficiency of yttrium achieved its maximum value of $92.0 \%$ after 15 min. Further increase in contact time to 20 min has negligible effect.

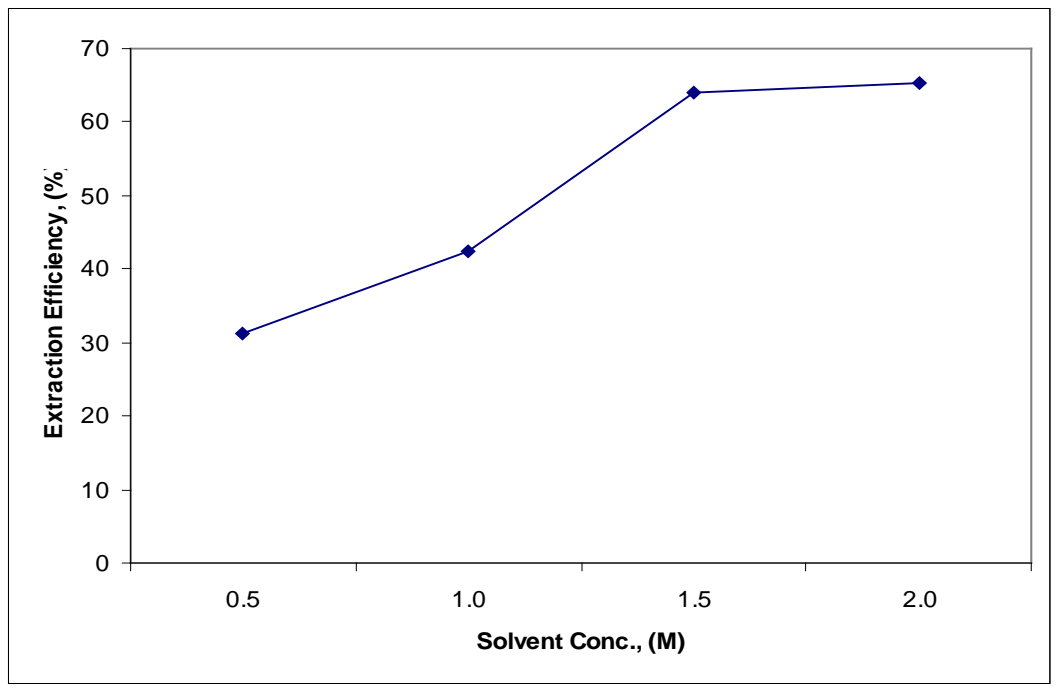

Figure (2): Effect of TBP concentration upon yttrium extraction efficiency at $\mathrm{pH}$ of $0.5, \mathrm{~A} / \mathrm{O}$ of $1 / 1$ and contact time of 10 min 


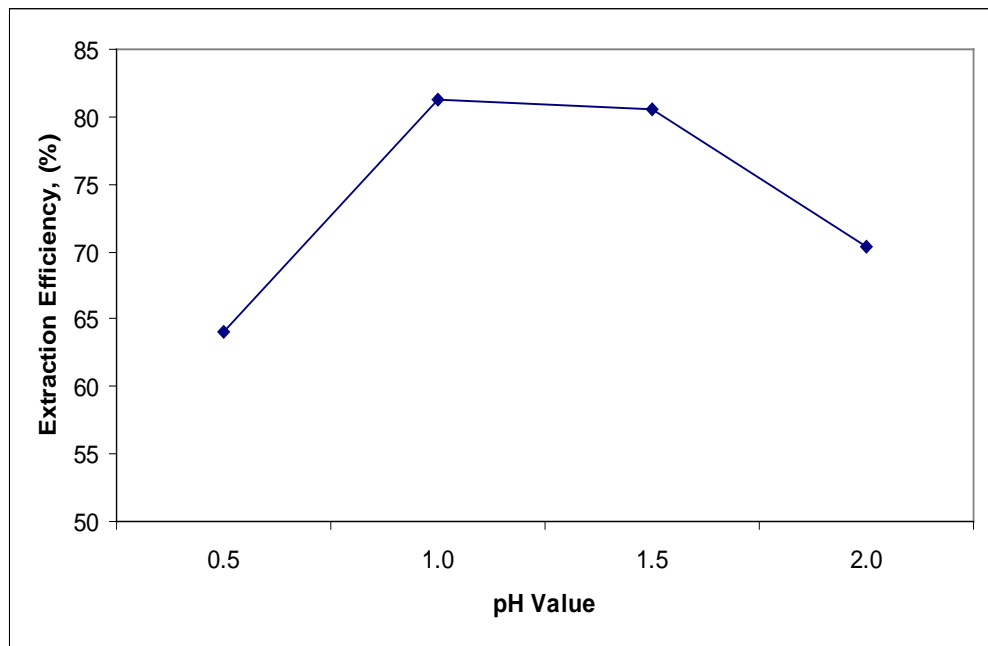

Figure (3): Effect of $\mathrm{pH}$ value upon yttrium extraction efficiency at $\mathrm{A} / \mathrm{O}$ ratio of $1 / 1$, TBP concentration of $1.5 \mathrm{M}$ and contact time of $10 \mathrm{~min}$

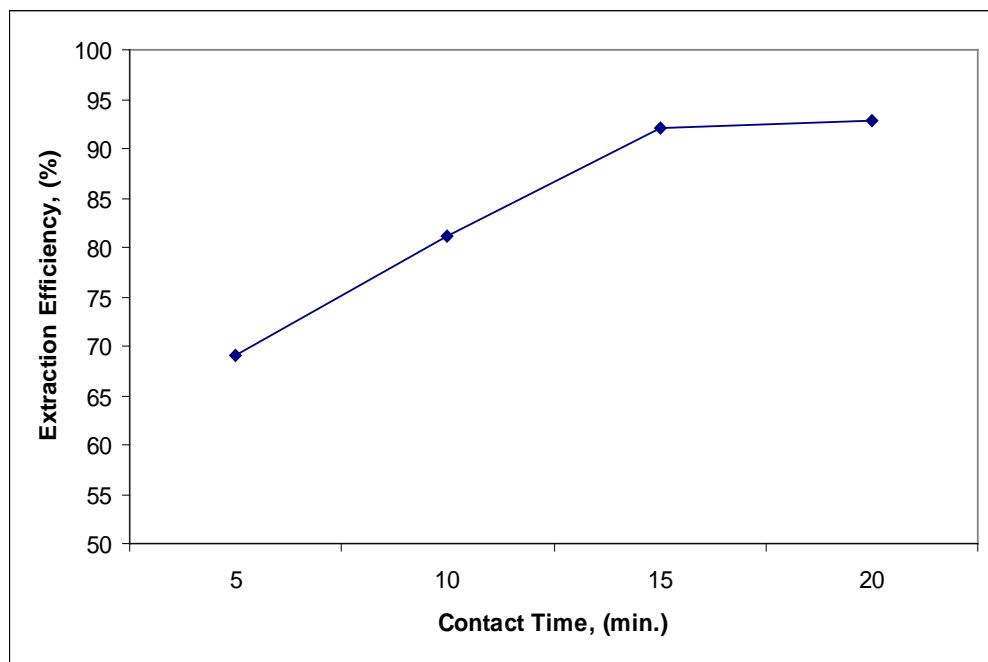

Figure (4): Effect of contact time upon yttrium extraction efficiency at $\mathrm{pH}$ of 1.0, A/O ratio of 1/1and TBP concentration of $1.5 \mathrm{M}$

Table (3): Effect of A/O ratio upon Y extraction efficiency (\%)

\begin{tabular}{|c|c|c|c|c|}
\hline A /O ratio & A Conc., ppm & O Conc., ppm & $D_{A}^{O}$ & $\begin{array}{c}\text { Extraction eff., } \\
\%\end{array}$ \\
\hline $1 / 4$ & 0 & 4250 & $\infty$ & 99.0 \\
\hline $1 / 3$ & 425 & 5525 & 13 & 97.5 \\
\hline $1 / 2$ & 850 & 8075 & $\begin{array}{c}9 . \\
5\end{array}$ & 95.0 \\
\hline $1 / 1$ & 1360 & 15640 & $\begin{array}{l}11 \\
.5\end{array}$ & 92 \\
\hline $2 / 1$ & 2040 & 29920 & $\begin{array}{c}14 \\
.66\end{array}$ & 88 \\
\hline $3 / 1$ & 4420 & 37740 & $\begin{array}{c}8 . \\
53\end{array}$ & 74 \\
\hline $4 / 1$ & 6290 & 42840 & $\begin{array}{c}6 . \\
81\end{array}$ & 63 \\
\hline
\end{tabular}

Arab J. Nucl. Sci. \& Applic. Vol. 51, No. 4 (2018) 


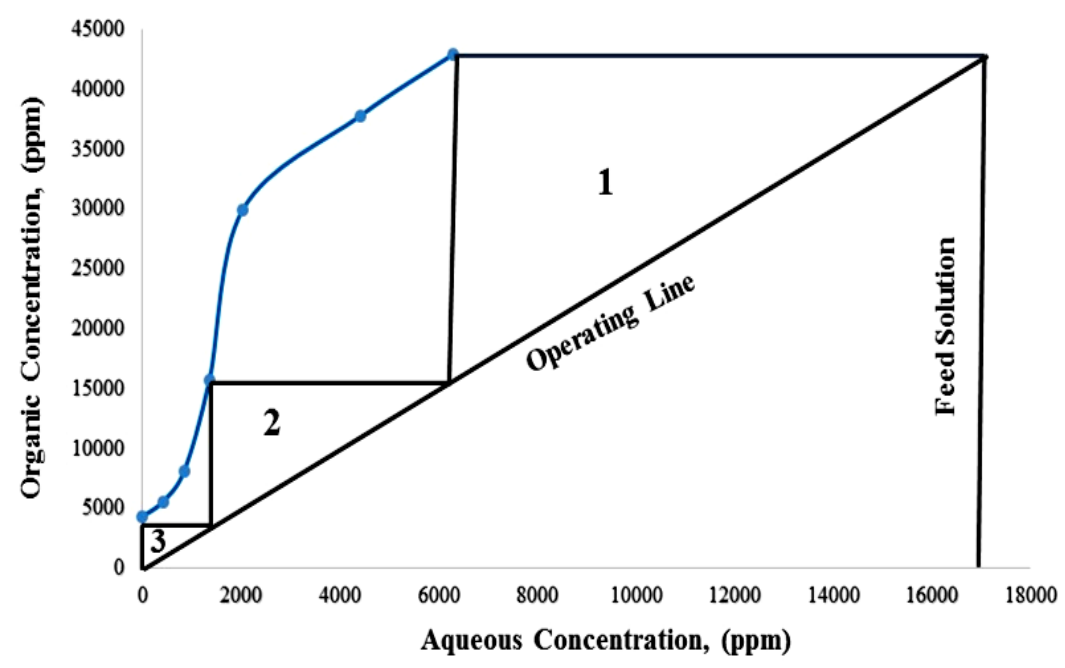

Figure (5): Effect of A/O ratios up on yttrium extraction efficiency at TBP concentration of 1.5M, contact time of 10min and pH1.0, ( McCabe Thiele diagram)

As shown from McCabe Thiele diagram in Figure(5), the extraction would be completed in three stages. From the obtained results, the optimum conditions for 92\% yttrium extraction (of $15.64 \mathrm{~g} / \mathrm{LY}_{2} \mathrm{O}_{3}$ ) from the concentrated RE nitrate solution were done at TBP concentration of $1.5 \mathrm{M}$, $\mathrm{pH}$ aqueous solution of 1.0 and $15 \mathrm{~min}$. shaking time at an $\mathrm{A} / \mathrm{O}$ ratio of $1 / 1$. The optimum conditions were applied using $80 \mathrm{~mL}$ of $\mathrm{Y}\left(\mathrm{NO}_{3}\right)_{3}$ solution. The loaded TBP was then directed to the stripping stage. Different affecting factors were studied for optimizing the stripping step as follows:

\section{Effect of stripping agent type}

The yttrium loaded TBP was stripped with different stripping agents e.g. hot $\mathrm{H}_{2} \mathrm{O}$ and $1.0 \mathrm{M}$ of $\mathrm{HCl}, \mathrm{HNO}_{3}$ and $\mathrm{H}_{2} \mathrm{SO}_{4}$, at $\mathrm{O} / \mathrm{A}$ ratio of $1 / 1$ and 5 min. contact time. After separation, the strip solution was analyzed for yttrium stripping efficiency. The obtained data revealed that the maximum $\mathrm{Y}$ stripping efficiency (35\%) was attained using 1.0 $\mathrm{M} \mathrm{H}_{2} \mathrm{SO}_{4}$, Fig (6).

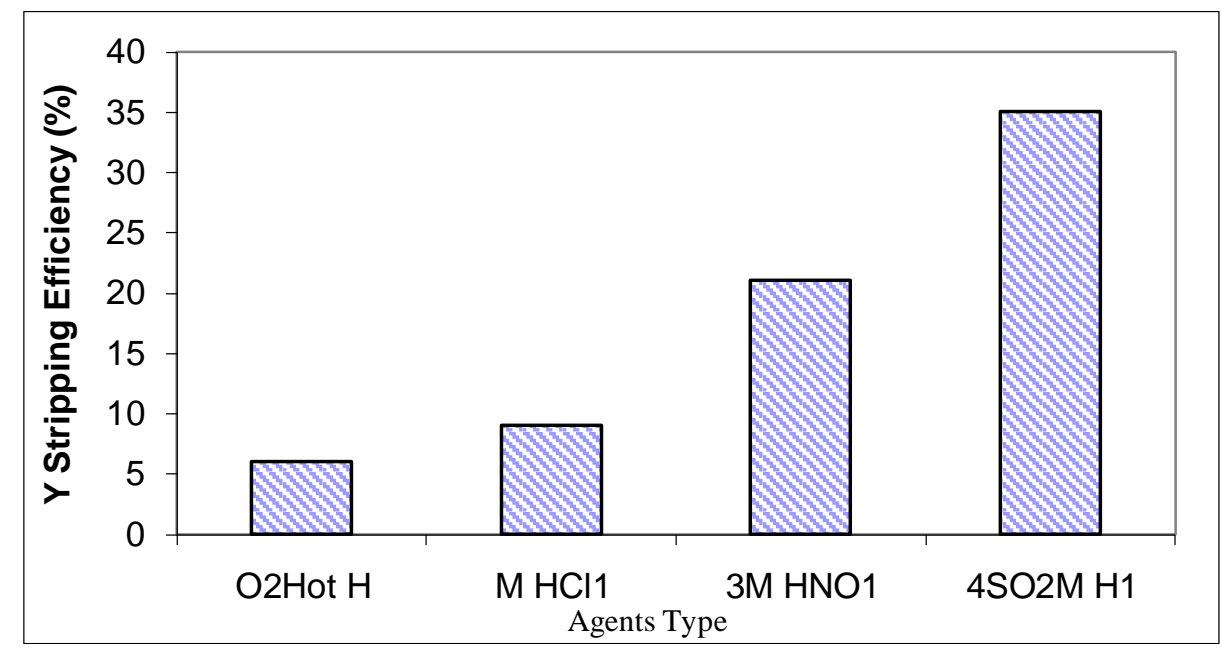

Figure (6): Effect of stripping agent's type upon yttrium stripping efficiency at O/A ratio of 1/1 and contact time of 5 min. 


\section{Effect of $\mathrm{H}_{2} \mathrm{SO}_{4}$ concentrations}

The yttrium loaded on TBP was contacted with $\mathrm{H}_{2} \mathrm{SO}_{4}$ strip solution of different concentrations ranging from 1.0 to $4.0 \mathrm{M}$. The other stripping parameters were kept constant at $\mathrm{O} / \mathrm{A}$ ratio of $1 / 1$ and 5.0 min. contact time. The obtained data in Figure(7) emphasized that yttrium stripping efficiency shows an improvement from 35.0 to $59.2 \%$ as the strip solution concentration increased from 1.0 to $3.0 \mathrm{M}$. Further increasing in $\mathrm{H}_{2} \mathrm{SO}_{4}$ concentration to $4.0 \mathrm{M}$ has limited influence.

Effect of contact time

The effect of changing the stripping time from 5.0 to 30.0 upon yttrium stripping percentage using $3.0 \mathrm{M} \mathrm{H}_{2} \mathrm{SO}_{4}$ solution at O/A ratio of $1 / 1$ Fig (8). It was noticed that yttrium stripping efficiency is strongly influenced by increasing the stripping time. It increased from 59.2 to $92.0 \%$ by increasing the contact time from 5 to $25 \mathrm{~min}$. almost no improvement in stripping after $25 \mathrm{~min}$.

Effect of O/A ratio
This factor not only represents the equilibrium state between both aqueous and organic phases, but also shows the suitable applied O/A ratio. The studied $\mathrm{O} / \mathrm{A}$ ratios ranged between $1 / 4 \ldots 1 / 1 \ldots$ $4 / 1$ using $3.0 \mathrm{M} \mathrm{H}_{2} \mathrm{SO}_{4}$ and 25 min. contact time. The obtained data in Table 4 revealed that yttrium stripping efficiencies $100,99.0$ and $97.0 \%$ were attained at $\mathrm{O} / \mathrm{A}$ ratios of $1 / 4,1 / 3$ and $1 / 2$, respectively. Practically, these ratios were not applied because the yttrium contents were diluted in strip solution which is not preferred to recover yttrium. On the other hand, yttrium stripping efficiency of 78.0, 60.0 and $46.5 \%$ were attained at $\mathrm{O} / \mathrm{A}$ ratios of $4 / 1,1 / 3$ and $1 / 2$, respectively. It was found that the yttrium concentration was of highest value at $\mathrm{O} / \mathrm{A}$ ratio of $1 / 4$, Table (4). Drawing McCabe Thiele diagram shows that stripping requires two stages to reach equilibrium Figure(9). The O/A ratio was selected to be $1 / 1$ for applying the precipitation step.

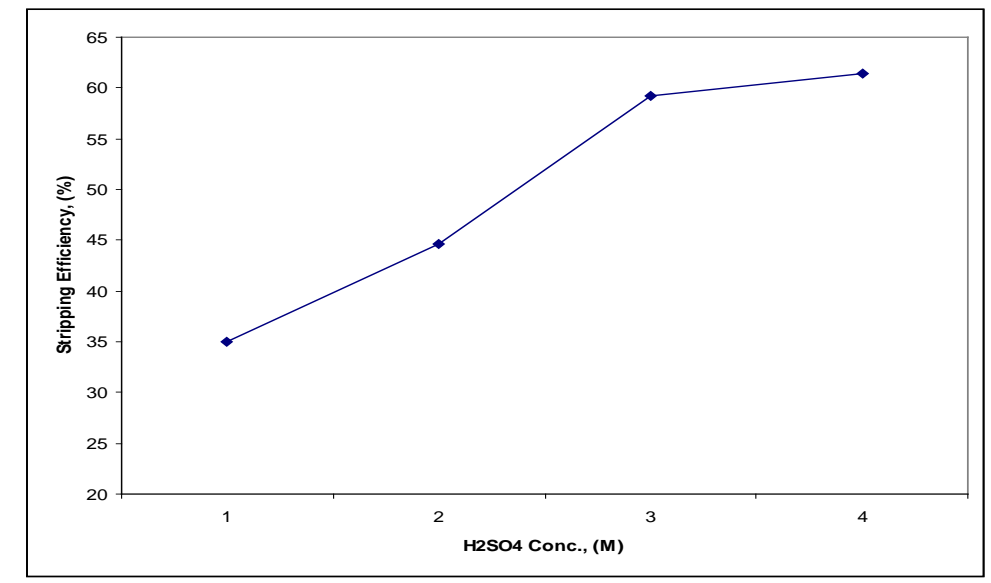

Figure (7): Effect of $\mathrm{H}_{2} \mathrm{SO}_{4}$ concentration upon $\mathrm{Y}$ stripping efficiency at $\mathrm{O} / \mathrm{A}$ ratio of $1 / 1$ and contact time of 5 min.

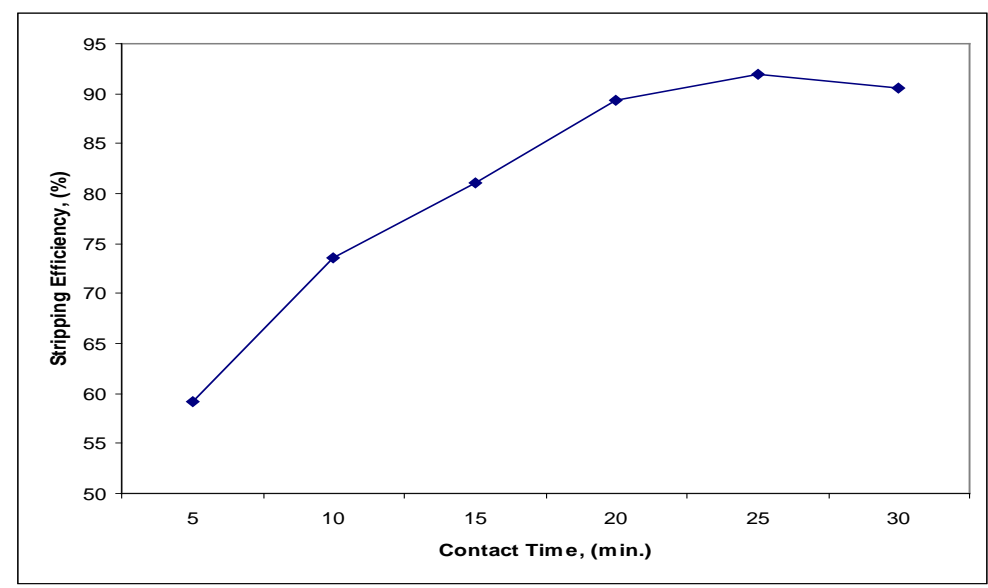

Figure (8): Effect of contact time of stripping upon yttrium efficiency at 3.0M $\mathrm{H}_{2} \mathrm{SO}_{4}$ strip solution and $\mathrm{O} / \mathrm{A}$ ratio of 1/1

Arab J. Nucl. Sci. \& Applic. Vol. 51, No. 4 (2018) 
The optimum conditions for regeneration $95.0 \%$ of yttrium from the loaded TBP are: $3.0 \mathrm{MH}_{2} \mathrm{SO}_{4}$ strip solution and shaking for $25 \mathrm{~min}$. at an O/A ratio of $1 / 1$.

\section{Preparation of $\mathrm{Y}_{2} \mathrm{O}_{3}$ final product}

Yttrium in the strip solution assaying $14.8 \mathrm{~g} / \mathrm{L}$ was precipitated by the gradual addition of $10 \%$ oxalic acid with continuous stirring for $60 \mathrm{~min}$. Almost complete precipitation of yttrium as a strong stable insoluble oxalate cake was attained at $\mathrm{pH}$ of 1.1 with $99 \%$ precipitation efficiency. After ignition at $950^{\circ} \mathrm{C}$ for $2 \mathrm{~h}, \mathrm{Y}_{2} \mathrm{O}_{3}$ was produced. A small portion of the latter was analyzed by means of XRD and SEM-EDAX to define its chemical composition as shown in Figs. (10 \& 11). On the other hand, another $0.1 \mathrm{~g}$ weight was completely dissolved in $25 \mathrm{~mL}$ volumetric flask and analyzed by both of UV-VIS spectrophotometer and ICP instruments for its purity. The obtained result showed that $\mathrm{Y}_{2} \mathrm{O}_{3}$ purity was not less than $97 \%$ with very low impurities of Si and Ca. Their lower concentrations were not detected by both XRD and SEM-EDAX analysis of the yttrium oxide product

Table (4): Effect of (O/A) ratio upon Y stripping efficiency, \%

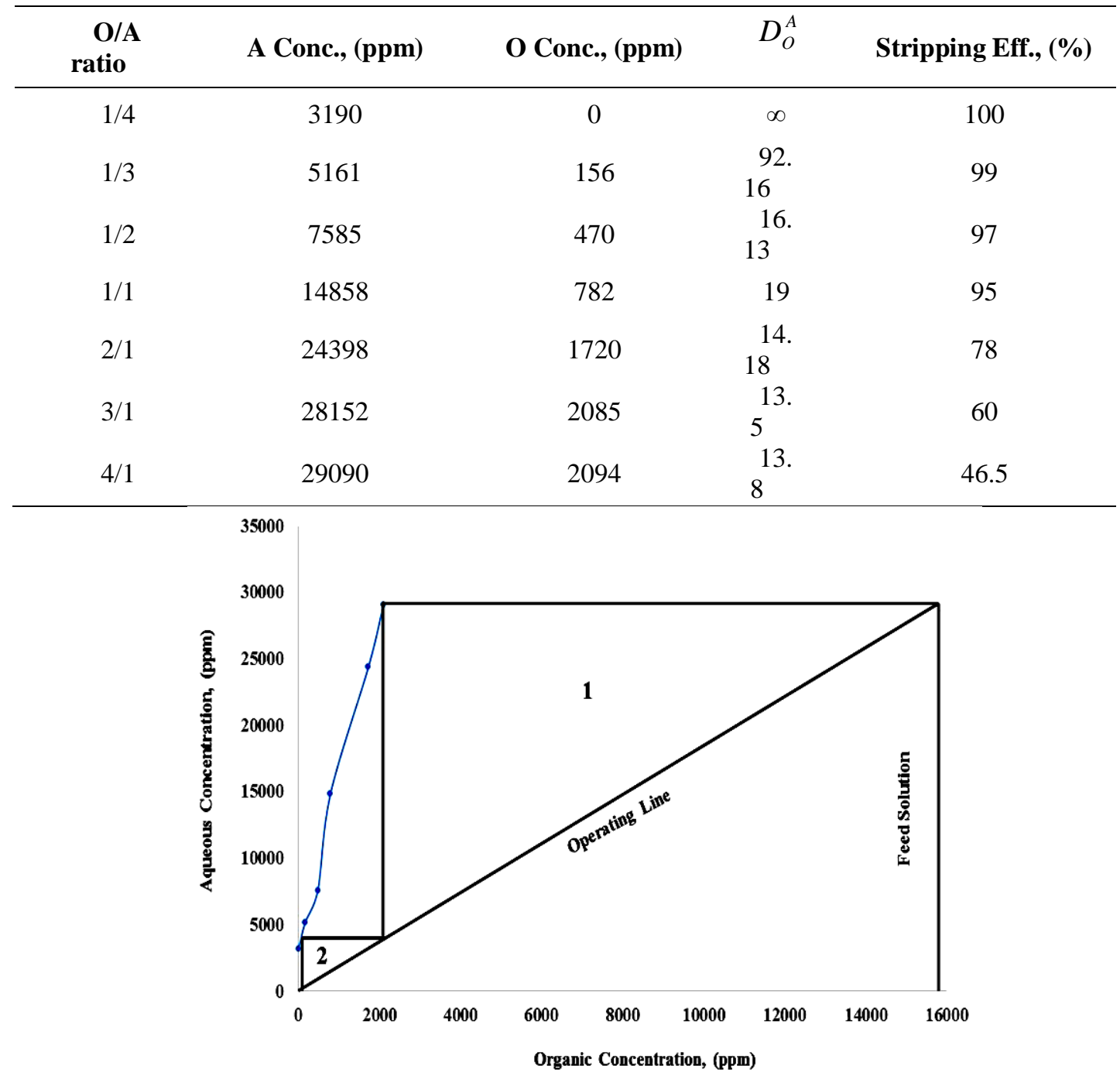

Figure (9): Effect of $\mathrm{O} / \mathrm{A}$ ratio upon $\mathrm{Y}$ stripping efficiency at contact time $25 \mathrm{~min}$ and $3.0 \mathrm{MH}_{2} \mathrm{SO}_{4}$ stripping solution, ( McCabe Thiele diagram) 


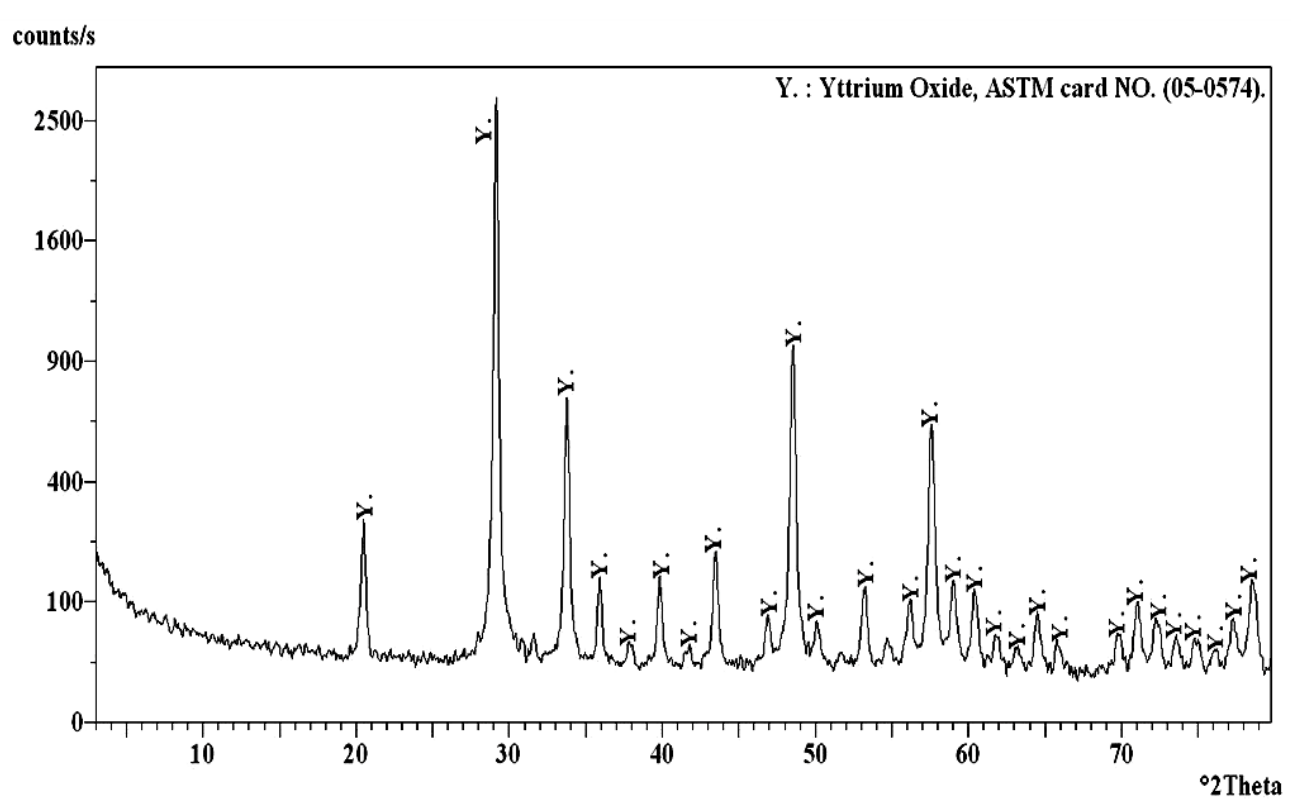

Figure (10): XRD pattern of pure $\mathrm{Y}_{2} \mathrm{O}_{3}$ product

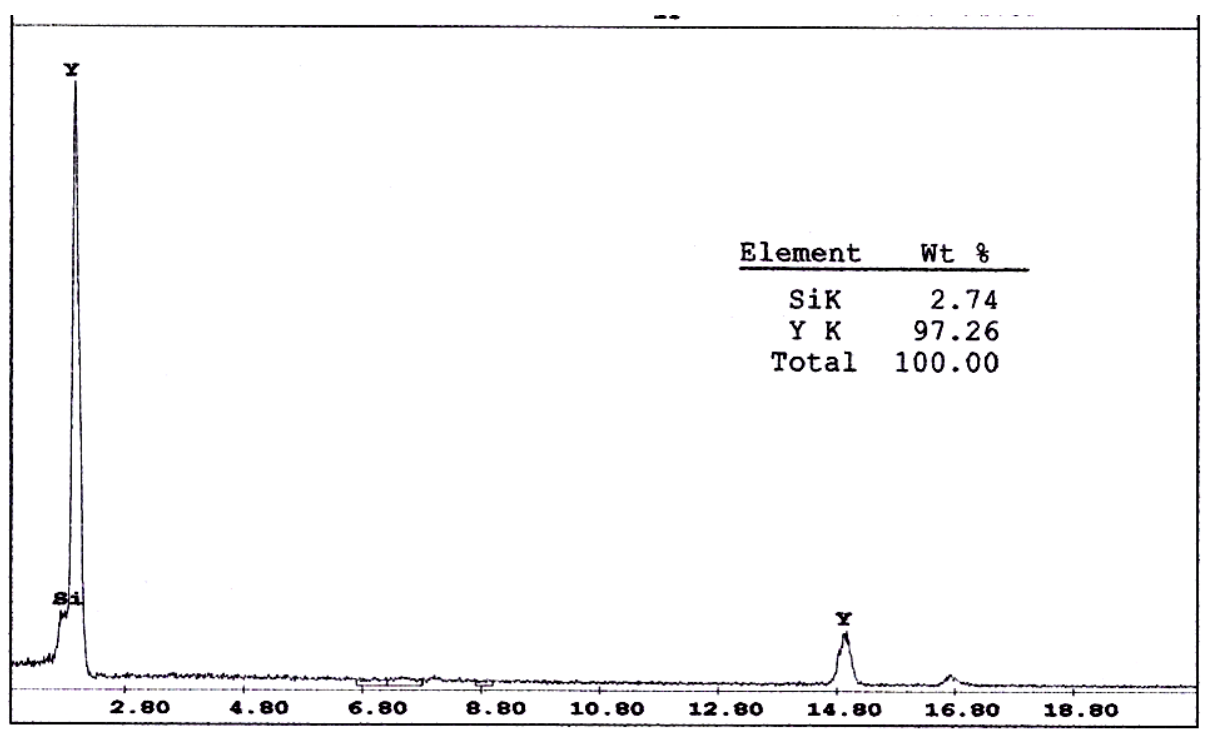

Figure (11): SEM-EDAX analysis of $\mathrm{Y}_{2} \mathrm{O}_{3}$ product

\section{Conclusions}

El Missikat fluorite- bearing ore material contains fluorides and $\mathrm{SiO}_{2}, \mathrm{Al}_{2} \mathrm{O}_{3}$ and $\mathrm{CaO}$ as major oxides in addition to low concentrations of REE, $\mathrm{U}$ and $\mathrm{Cd}$. Two successive roasting processes of $\mathrm{El}$ Missikate fluorite- bearing ore material were performed using $10 \%$ (wt/wt) $\mathrm{MgO}$ followed by $1 / 2$ (wt/wt) $\left(\mathrm{NH}_{4}\right)_{2} \mathrm{SO}_{4}$ salt to deactivate the fluoride. Fluorine deactivated matrix was leached with distilled hot $\mathrm{H}_{2} \mathrm{O}$ at $\left(80-90^{\circ} \mathrm{C}\right)$ at $\mathrm{S} / \mathrm{L}$ ratio of $1 / 2$ and stirring for $2 \mathrm{~h}$ to prepare the solution. Precipitation of REE was attained by addition of

Arab J. Nucl. Sci. \& Applic. Vol. 51, No. 4 (2018) 20g/l oxalic acid at $\mathrm{pH}$ of 1.1 after 60 min stirring with $98 \%$ precipitation efficiency.

The ignited REE cake was dissolved in 31.5\% nitric acid with $\mathrm{S} / \mathrm{L}$ ratio $1 / 3$ for $2 \mathrm{~h}$ at $70^{\circ} \mathrm{C}$ for yttrium extraction by tri-butyl phosphate (TBP) from the nitrate solution.

The optimum extraction conditions of yttrium were: $15 \mathrm{~min}$. contact time, $\mathrm{pH}$ of 1.0 and1.5 M solvent concentration at $\mathrm{A} / \mathrm{O}$ ratio $1 / 1$.Yttrium strip from the loaded organic phase was achieved by $3.0 \mathrm{M}$ of $\mathrm{H}_{2} \mathrm{SO}_{4}$ at $\mathrm{O} / \mathrm{A}$ ratio $1 / 1$ for $25 \mathrm{~min}$ contact time. Yttrium was precipitated from the strip solution by addition of $10 \%$ oxalic acid 
gradually to the solution with stirring until almost complete precipitation. The obtained yttrium oxalate precipitate was filtered, washed, dried and ignited at $950^{\circ} \mathrm{C}$ to yield an $\mathrm{Y}_{2} \mathrm{O}_{3}$ with $97.2 \%$ purity.

\section{References}

1- Zhou, J., Duan, W., Zhou, X. and Zhang, C., Application of Annular Centrifugal Contactors in the extraction flowsheet for producing high purity yttrium. Hydrometallurgy, 85, 154-162 (2007).

2- Amer, T, E., Ibrahem, T.M. and Omar, S.A., Micro- Prope Studies and some Rare Metals Recovery from EL-Missikat Mineralized Shear Zone Eastern Desert, Egypt. The fourth International Conference on The Geology of Africa, Assiut, Egypt. 2, pp.225-238 (2005).

3- Abd El Warith, A., Michalik, M. and Ali, A.H., Fluorine Enriched Granites: Chemical Characterization and Relation to Uranium Mineralization. J. of Applied Sciences Research, 6 (4) pp. 299-323 (2010).

4- EL-Sherif, A.M., Mineralogical Characterization of the alteration faces at Gabal EL-Missikat area. Nuclear Sciences Scientific Journal, 2, pp 1-21 (2013).

5- Raslan, M.F., Mineralogical and geochemical characteristics of uranium-rich fluorite in ELMissikat mineralized granite, Central Eastern Desert, Egypt. Geologija 52/2, pp. 213-220 (2009).

6- Chi, X. Zhang, Zhu, G. , Zhou, Z.A., Wu, Y., Wang, C. and Yu, F., Recovery of Rare Earth from Bastnasite by Ammonium Chloride Roasting with Fluorine Deactivation , Minerals Engineering, 17, pp.1037-1043 (2004).

7- Bauer, D.J., Development of equipment and process for extracting cerium (IV), Bu. Mines RI 5536, US Dept. of Interior, Washington, D.C. (1959).

8- Mathur, J.N. and Choppin, G.R., Paraffin wax as a diluent for extraction of actinides and Lanthanides with TBP. Solvent Extr. Ion Exchange. 16, 459 469 (1998).

9- Singh, D.K., Singh, H., Mathur, J.M., Extraction of Rare Earths and Yttrium with high molecular weight carboxylic acids. Hydrometallurgy 81, 174 181 (2006).

10- Hubicki, Z. and Olszak, M., Studies of sorption and separation processes of rare earth complexes on the anion exchanger Wofatit SBW in the $\mathrm{CH} 3 \mathrm{OH}-$ HNO3 system, Hydrometallurgy., 50, pp. 261-268 (1998).

11- Djingova, R. and Ivanova J., Determination of Rare Earth Elements in Soils and Sediments by Inductively coupled plasma Atomic Emission Epectrometry after Cation-Exchange Separation. Talanta 57, pp.821-829 (2002).

12- Abd El Wahab, G.M, Amer, T.E., Abu Khozaim H.A., Abd El kader, N.A., El Sewafy, S.K. and Mahdy, R.M. Extraction of Boron and Magnesium from El Max Saline Bittern Solution. Internal Report, Nuclear Materials Authority, pp. $1-15$ (2016).

13- Shapiro, L. and Brannock, W.W., Rapid Analysis of Silicate Carbonate and Phosphate Rocks. U.S. Geol. Surv. Bull., P 114 (1962).

14- Marczenko, Z., "Spectrophotometric determination of elements", John Wiley and Sons, Harwood, New York (2000).

15- Yang, J., Dai, S., Pan, X., Liu, L., Zhou, S., Wang, J., "Determination of uranium in ore with volumetry of H2SO4-TICL3-NH4VO3". Applied Mechanics and Materials Vols. 511-512, pp 12-16 (2014).

16- Habashi, F., A textbook of hydrometallurgy, Metallurgic extractive Quebec, Eng., Quebec, Canada (1993).

17- Abdellah, W., M., Recovery of Rare Earths and some Associated Elements from East Abu Zeneima Gibbsite Deposits, Sinai, Egypt, M.Sc. Thesis, Chemistry Department, Faculty of Science, Ain Shams University (2009).

18- Woyski, M.M. and Harris, R.E., "The Rare Earths and Rare Earth Compounds". In Kolthoff, I.M.; (ed.), "Treatise on Analytical Chemistry", Part II, Vol. 8, John Wiley \& Sons Inc., New York, pp.1146 (1963).

19- Khalafalla, M., S. Extraction of Some Nuclear Elements from Ferruginous Sandstone from South. Western Sinai, Egypt M.Sc. Thesis, Chemistry Department, Faculty of Science, South Valley Univ. (2013). 